Article

\title{
Equity vs. Efficiency and the Human Right to Water
}

\author{
Manuel Prieto (D)
}

check for

updates

Citation: Prieto, M. Equity vs. Efficiency and the Human Right to Water. Water 2021, 13, 278. https:// doi.org/10.3390/w13030278

Academic Editors: Bruce M. Wilson, Malcolm Langford and

Rebecca Schiel

Received: 12 December 2020

Accepted: 21 January 2021

Published: 24 January 202

Publisher's Note: MDPI stays neutral with regard to jurisdictional claims in published maps and institutional affiliations.

Copyright: (C) 2021 by the author. Licensee MDPI, Basel, Switzerland. This article is an open access article distributed under the terms and conditions of the Creative Commons Attribution (CC BY) license (https:// creativecommons.org/licenses/by/ $4.0 /)$.
Departamento de Ciencias Históricas y Geográficas, Universidad de Tarapacá, Arica 1000965, Chile; mprieto@academicos.uta.cl

\begin{abstract}
One of the most crucial discussions within water resource management is the debate between those who defend the concept of economic efficiency and those who privilege notions of social equity. This tension is located at the core of binary categories that currently constitute the public debate within comparative water law and policy. These categories are commodity/human right, private property/common property, free-market/state regulation, and market value/community value. This paper explores this tension by studying how neoclassical economics understands efficiency and tracing its rise as a key hegemonic principle for water resource management. I also present equity as a conceptual opposition to efficiency and describe its institutionalization through the human-right-to-water frame. A problematization of both the equity approach and the humanright-to-water frame follows. Finally, I propose a political ecology approach to better understand the tension between efficiency and equity and offer recommendations for informing the water research agenda on efficiency/equity.
\end{abstract}

Keywords: water policy; equity; economic efficiency; human right to water

\section{Introduction}

In 1967, Maurice Kelso [1], alarmed by the lack of a market in Arizona that would facilitate water transfers from agriculture to highest value uses, wrote a pioneering defense for the commodification of water. In his opinion, water had become subject to what he calls the "water-is-different syndrome". By this concept, he meant that water had become imprisoned by several myths claiming it could not be privatized, was outside ordinary market mechanisms, and was priceless. In Kelso's opinion, water is "not different" and should be treated as an ordinary commodity. He argues that this statement is a fact that can be objectively confirmed by experience and perspectives that defend the idea that "water-is-different" are grounded in false judgments based on subjective beliefs. For Kelso, "subjective belief[s] about water [ ... ] are not nature-imposed imperatives but dictates of their own emotions which, also, if taken too seriously, can imperil society" [1], p. 177. What imperils society is that the "water-is-different syndrome" poses a serious obstacle to optimum overall economic efficiency. In sum, for Kelso, water is objectively a commodity, while any other perspective is subjective and endangers efficiency and, consequently, society.

In Arizona, the same place where Kelso identified the "water-is-different syndrome", the Tohono O'odham (Native American people of the Sonoran Desert (currently in the U.S. state of Arizona and the Mexican state of Sonora)) hold a ritual called the viikita every four years. The viikita aims to ensure copious rains and abundant water for Tohono $\mathrm{O}^{\prime}$ odham crops. Observing this ritual and other collective practices carried out by the Tohono O'odham and by the Hispanic communities of the Southwest, Helen Ingram asserts that they constitute a form of collective power over water, illustrating what she calls the "community value of water" [2]. The community value of water supposes a collective social organization and management of water in order to ensure social equity.

Thus, Kelso and Ingram-two scholars studying the same phenomenon, water management in Arizona, at the same university_arrived at radically different conclusions. For 
Kelso [1], the community value of water is a syndrome that threatens economic efficiency insofar as it impedes water flowing from Tohono O'odham agriculture toward highest value uses. However, for Ingram [2], the community value of water ensures social equity which, in fact, is threatened by utilitarian perspectives on economic efficiency that reduce the value of water to a price [3].

The above discussion illustrates an important tension within contemporary water resource management: the tension between the concepts of efficiency and equity. This tension is not isolated from other relevant discussions, and indeed it is at the core of the binary categories that currently constitute the debate within comparative water law and policy. These are commodity/human right, private property/common property, free market/state regulation, and market value/community value. This paper explores the basic tension between equity and efficiency. Following this introduction, the second section describes the neoclassical economics understanding of efficiency and demonstrates that this concept has become naturalized through a scientific perspective, moralized by a utilitarian approach, and institutionalized by the law and economics model. In what follows, I first explore how the idea of economic efficiency has become a key hegemonic principle for water resource management. Second, I analyze the main problems with the overemphasis on efficiency in water resource management. Third, I present the idea of equity as a conceptual opposition to efficiency and its institutionalization through the human-right-to-water frame. Fourth, I problematize both the equity approach and the human-right-to-water frame. Finally, I propose a political ecology approach for a better understanding of the efficiency/equity tension. This is followed by four recommendations for informing the water research agenda on efficiency/equity.

\section{Economic Efficiency: What It Is, and How It Became Natural, Moral, and Institutionalized}

In simple terms, efficiency describes a situation where a certain level of utility (i.e., a measure of satisfaction) is reached by maximizing resources in the least expensive way possible. Under the basic assumption that utility can be measured objectively, orthodox economic theory stopped focusing on ordinal efficiency (i.e., where no other allocation of goods improves all agents) during the nineteenth century and adopted a model of cardinal utility (i.e., the satisfaction of a commodity allocation can be measured with a numeric value). This turning point allowed both interpersonal and aggregative measures of welfare and, consequently, comparisons between different states of society. Based on this assumption, the concept of economic efficiency became the hegemonic foundation for any collective action regarding economic regulation in general and natural resource policy in particular. The perspective of law and economics, replacing traditional standards of fairness and justice, uses the concept of economic efficiency as the primary standard for any legal decision, no matter if it is directly related to economic issues. Within this context, the Kaldor-Hicks potential compensation test is the dominant formulation used as a standard for cost-benefit analysis in policy prescriptions [4,5]. In brief, for heterodox economics, efficiency equals Kaldor-Hicks compensation. In this section, I will, first, explain the Pareto efficiency criterion as the base upon which the Kaldor-Hicks test is formulated, which is explained later. The influence of this efficiency imaginary has been significant for understanding both the post-Washington Consensus water reforms and critiques of them. The Washington Consensus is a set of neoliberal economic policy prescriptions for developing countries. The term refers to the level of agreement between Washington, D.C.-based institutions such as the International Monetary Fund, World Bank, and the U.S. Department of the Treasury. The prescriptions promote a free market and minimal state. For details, see Conca [6].

\subsection{The Efficiency Standards: Pareto and Kaldor-Hicks}

Pareto [7] formulated the most classic and influential conceptualization of efficiency. Interpreted in a broad sense, Pareto efficiency exists when no alteration in the current state of resource allocation in society could make at least one member better off without making 
someone else worse off. Consequently, Pareto improvement exists as long as winners in an allocation decision compensate the losers and retain a surplus. Translated into policy terms, at a social level, when the possibilities of making a Pareto improvement are zero, society is organized under an efficient model of resource allocation that cannot be modified without making someone worse off. However, legal changes inevitably produce winners and losers; they promote some members' well-being at a cost to others. This situation is why, as formulated above, the Pareto criterion can only be a standard in an ideal society [5,8].

Pareto's ideal scenario is transformed into a realistic one by the Kaldor-Hicks test. This test sees efficiency as a situation where no reallocation of resources could increase the total social welfare. In this sense, a Kaldor-Hicks improvement supposes that any reallocation is efficient under two copulative conditions:

1. The reallocation creates benefits for some members of society.

2. These benefits are greater than the losses suffered by other members of society.

In simple terms, for Kaldor-Hicks efficiency, Pareto compensation never occurred. It is subsumed by the increase in the aggregative general social welfare. This compensation is the utilitarian trick that, popularized by Posner under the concept of wealth maximization, has become the golden criterion of cost-benefit analysis in the dominant technocratic public decision-making process.

\subsection{Kaldor-Hicks, Efficiency, and the Free Market: A Naturalized Trilogy}

For neoclassical economics, within a scenario of competitive equilibrium, efficiency is spontaneously achieved as formulated above. This connection between efficiency and a perfect market economy constitutes the main argument for supporters of a laissez-faire economy and, within the context of water, the promoters of private rights and free markets as the core principles of water management.

A perfectly competitive economy in equilibrium is the core of the neoclassical explanations for how the economy works. According to this model, prices reach equilibrium under the law of supply and demand. At the same time, this situation allows society to maximize its surplus as long as both consumers and sellers maximize their surpluses (i.e., their marginal benefits). This model is clearly anchored in Smith's invisible hand theorem, where self-interest and competition, operating within a system of decentralized markets, maximize general social welfare, and consequently, Kaldor-Hicks efficiency.

On the other hand, under a regulated economy model (i.e., through taxes and/or subsidies), perfect competition is altered along with prices. Under this scenario, the buyer's or seller's surpluses are altered, producing a wealth transfer that constitutes a social cost (i.e., deadweight loss). As long as this cost diminishes the general social welfare, neoclassical economics considers it a loss of economic efficiency. In addition to the deadweight loss, a regulated economy also produces what Chicago School (Chicago School is a neoclassical economic school of thought that promotes the principle that a free market and minimal or no government intervention ensures economic prosperity) [9-11] has called "the rent-seeking society." This concept refers to a society where regulations motivate interest groups to lobby in pursuit of private benefits. These investments in rent-seeking represent a double barrier to efficiency: First, resources are oriented toward lobbying, and second, this situation results in a regulated redistribution that leads to a socially undesirable allocation of resources [12,13].

This dominant understanding presents economic efficiency as a natural phenomenon in the triple sense proposed by Williams [14]. First, efficiency is seen as an essence of some economic behavior. Second, it appears determined by an inherent force that is universal and can be discovered through the scientific method. Third, efficiency is considered to exist by itself, external to and independent from cultural phenomena. Considering this triple naturalization, efficiency is seen as inevitable, completely isolated from any broader social context, and the object of scientific inquiry. Under this focus, efficiency is reduced to a technical problem, which can be solved by the apolitical tools of econometrics and explained through the supposedly objective language of numbers. 


\subsection{The Model Meets Its Moral Ideology: Utilitarian Foundations of Economic Efficiency}

Utilitarianism is a perspective on ethics that can be summarized under the motto that what is morally acceptable produces the greatest happiness for the greatest number of people $[15,16]$. In policy terms, this means that policies should be evaluated according to the general social utility they produce [15]. Despite the different variants of utilitarianism (e.g., Mill and Bentham), all share common premises. As summarized by Sen and Foster [17], these premises are as follows: (a) Only consequences are relevant, (b) these consequences are evaluated according to the utility they produce, and (c) maximum levels of utility in such consequences ought to be reached. Although classic utilitarianism did not embrace a model of efficiency as described above, those who defend this model have encountered in utilitarianism a moral standard for justifying their model.

Consequently, economic efficiency, in addition to being naturalized as an apolitical phenomenon, is also justified as morally right under utilitarian ethics. What allows this movement is the confusion of happiness with welfare; consequently, an increase of the general social welfare comes to mean an increase of general social happiness, which is the fundamental moral standard for utilitarianism. In this sense, utilitarian theories appear as a teleological means for justifying a welfarist theory of value [18].

\subsection{Institutionalizing Efficiency: Law and Economics}

One of the most radical turning points in the contemporary history of legal thought is constituted by the emergence of the law and economics approach. The radical nature of this approach to law is determined by the shift that it produced on the foundational categories of legal thought and legal change.

Justice is a broader concept that relies on equity as an ideal that should inform its normative content along with legal deliberation. In other terms, "equity is the necessary condition for a just society" [3], p. 8. However, law and economics scholars anchor justice in objective and universal economic efficiency. Under this approach, justice and equity are nebulous, complex, and contested concepts that, as such, offer no clear directions for legal reasoning. On the contrary, economic efficiency is accurate enough to arrive at unbiased, universally applied, and precise legal decisions that avoid any subjective aspirations. Consequently, the new basic standards for both understanding the legal phenomenon and optimizing it are determined by Kaldor-Hicks efficiency models society [5]. Under this logic, law and economics takes the neoclassical perspectives and uses them as a privileged dogmatic legal model [19]. In practical terms, this produces a powerful idea: The law should not guarantee a particular aspiration of equality to achieve justice through rules of command and control; rather, it should establish a system of incentives in order to maximize Kaldor-Hicks efficiency. Trying to create equilibrium between utilitarianism and individual choice, Posner [20] justifies this model under a neo-contractual theory that presents subjects as giving consent on an ex-ante compensation agreement.

How did these ideas become institutionalized? Under the law and economics model, legal institutions should be designed in order to promote efficiency. This supposes:

1. Private property. This allows an efficient internalization of externalities, which is impossible under common property insofar as it involves prohibitive transaction costs [21].

2. Free market. Centralized models are inefficient inasmuch they increase the deadweight loss and lack the necessary information for the right distribution of goods; on the contrary, a system of market prices gives the correct information to individuals for efficient resource allocation [22].

3. Freedom of contract. Unlike the classic legal dogmatic approach that views contracts as a mean of exerting subjective freedom, the law and economics perspective views contracts as a mean for reaching the objectives of welfare economics. Thus contracts are a key instrument for communicating personal preferences in order to reach efficiency [23]. The main consequence of this perspective is that contracts are not a means to reach ideals or aspirations of equity; instead, law should be designed according to 
contract requirements under neoclassical economics: to define and enforce property rights and diminish transaction costs.

4. Judges. Judges should mimic, in their decisions, the efficient outcomes of the market [20].

5. Regulations. Regulations are not understood as a system that codifies norms and social conventions; rather, they are seen as establishing a system of incentives.

Under the previous model, an efficient distribution of goods will theoretically be reached as a natural effect caused by the valorization of goods through price signals. These prices, emerging from the individual decisions involved in transactions of private property through contracts performed within unplanned markets, provide the right economic incentive to encourage the movement of resources from lower to higher value uses [23]. This is what maximizes Kaldor-Hicks efficiency and, consequently, general social welfare.

In this section, I have shown the processes by which economic efficiency has been naturalized, moralized, and institutionalized, the basic steps for any hegemonic project. In the next section, I explore the role this idea has played as a key driver for recent water management reforms.

\section{The Entanglement between Water Management and Economic Efficiency}

The post-Washington Consensus era has been characterized by a broader process of structural adjustment, privatization, and trade liberalization that has expanded neoliberal economic reforms and, with them, the aforementioned conceptualization of efficiency to all kinds of economic sectors. Within this context, and as a solution to the "tragedy of the commons" - the tragedy of the commons is an economics problem in a shared-resource situation in which individual self-interest causes the avoidance of collective action and ultimately results in the overexploitation of common goods [24] —environmental governance has been highly influenced by the idea of "free-market environmentalism" as the ideal model for natural resource distribution [25]. Applying law and economics principles to environmental management supposes that the allocation of both environmental goods and degradation/pollution reaches the highest economic efficiency through a system of private property rights, free market allocation mechanisms, and zero transaction costs. Influenced by Coase [23] and Cheung [26], and rejecting the Pigouvian approach (i.e., taxes on markets intended to correct an undesirable or inefficient market outcome), free-market environmentalism presents the market as the solution for-rather than the source of-environmental problems and inefficiency. Water has not escaped this approach. On the contrary, the water sector is a paradigmatic case that illustrates how institutional reforms, implementing efficiency in light of free-market environmentalism, have marked a turning point in water management.

During most of the twentieth century, the dominant paradigm for managing water was based on a state driven model known as the modern "hydraulic empire" [27], the "hydraulic paradigm" [28], or the "municipal hydraulic paradigm" [29]. Assuming plentiful water supplies (but recognizing uneven spatial distribution) and unavoidable growth of water demand, this paradigm is characterized by a supply management that relies on the use of public hydraulic infrastructure and government ownership and/or strict government command and control regulation [29]. Although this paradigm was framed under the discourse of universal provision and equity, results show inequitable effects (e.g., impacts to aquatic species/ecosystems, displacement of people/communities from areas that become inundated by dams, and water dispossession of people/communities whose water was redistributed). Swyngedouw [30] illustrates this model through the Spanish case, where the Franco dictatorship overcame the unequal temporal and spatial distribution of water through public works that massively transformed the Spanish water landscape, including ecosystems, water access, and water control. Similarly Worster [27], applying Wittfogel's [31] thesis on hydraulic societies, shows that the development of the water infrastructure in the US's arid West was based on a significant involvement of the federal government in constructing and managing water infrastructure, constituting a modern 
"hydraulic empire" controlled by a water elite. However, this model favors large-scale irrigation, transforming the US West in ways to satisfy national settlement goals at the cost of severe long-term adverse effects on the environment and water quantity [32].

In the early 1980s, this state-centered model came under attack by the "state failure" discourse. This critique determined the emergence of a system focused on efficiency which, as shown above, is achieved through pricing, private property, and tradable rights.

The narrative of state failure positioned the state as the source of a water crisis. Following libertarian ideas (e.g., Hayek [33]), the state is seen as influenced by interest groups (the above idea of "the rent seeking society"), and consequently, the economy is perceived as ideologically altered, efficiency as not maximized, and political freedom as threatened. From this perspective, the state appears as a discretionary power with regard to water sanitization and distribution, a source of highly inefficient outcomes and underproduction, a product of the failure to reach either social or environmental goals, and a threat to political freedom. As an alternative to the state-centered approach, free market environmentalism emerges as the ideal model for conducting water toward efficiency and political freedom [34]. For Kelso "[1], free market environmentalism is the medicine for the "water-is-different syndrome".

Since the 1990s, state failure and market environmentalism discourses have exercised a strong influence on comparative water law and policy and international development and policy debates [6]. A clear example of this is found in the 1992 "Dublin Principles" — the 1992 International Conference on Water and the Environment became known as the "Dublin Principles". Diverse international agencies have embraced these principles. For details, see Conca [6] - the fourth of which is commonly used to illustrate this shifting paradigm: "Water has an economic value in all its competing uses and should be recognized as an economic good [ ... ]." Despite the fact that this principle does not explicitly mention free market environmentalism and private property as the model for water management, influential economists (e.g., Thobani [35] and Briscoe [36]), embracing narrow economic perspectives and supported by international development agencies (e.g., Word Bank, International Monetary Fund, and diverse regional development banks), have interpreted this principle in such a way that water is presented as a full commodity [37]. This leads to privatization of both water and water services, full cost pricing, market mechanisms, and a declining role of the state, as the means to reach high economic efficiency [6].

Following these ideas, narrow economic perspectives argue that fully tradable property rights to water will reduce the inefficient allocation and use of scarce water because the market will neutrally price the resource according to its true scarcity value [37]. The basic assumption here is that prices will create incentives for water to flow toward its highest value, ensuring the internalization of negative externalities, the promotion of technological investment for maximum use and increased productivity, and private investment that ensures economic growth. In order to achieve these goals, the market must be as free as possible, with a state whose only role is to ensure the protection of private property, the enforcement of contracts, and the prevention of market failure. In sum, the entire efficiency set of economic policy prescriptions arrived at the water sector, and law and economics became the model for water issues.

The narrative behind this model mirrors and details the discourse on economic efficiency described in the previous section. Thus, economic efficiency in water management implies an allocation in such manner that no further reallocation is possible that would provide gains in production and consumption or consumer satisfaction to some water users without simultaneously imposing losses to others [38], p. 3.

Since there are always losers, Ingram [38] observes that economists have created the necessary hypothetical tool for solving this noise in the model: in this case, the Kaldor-Hicks test. Authors who defend a water demand management system (i.e., the development and implementation of strategies aimed at influencing water demand to achieve efficiency) based on water markets expressly use the narrative of efficiency, its neutral language, and apolitical rhetoric. For example, Briscoe, in an influential paper, implements the same 
model to show water demand and supply and to justify the market based model for water allocation as a condition for reaching highest water efficiency $[4,36]$.

The literature has documented how broad (and also contradictory) the influence of this model has been around the globe. Examples include the imposition of fully tradable property rights in Chile [39], the creation of both water markets and water banks in Spain [40], the privatization of water supply infrastructure in England and Wales [41], the termination of state control of water quality mechanism in Ontario [42], the creation of water markets in Tenerife [43], the introduction of the full cost recovery principle in water management in South Africa [44], the decentralization of water management in Mexico [45], and the privatization of water services in Cochabamba [46], among others.

\section{Water Management and Economic Efficiency: Criticizing the Entanglement}

The only truly natural feature of discourses that naturalize reality is that they are naturally problematic. Efficiency as presented above is a phenomenon that, existing by itself, has an inevitable essence, follows universal rules, and exists as isolated from broader social and ecological contexts. These assumptions are extremely dangerous for water debates so long as water problems are presented as simple technical problems. When this imaginary becomes hegemonic, discussion is replaced by universal and apolitical solutions that, appearing as neutral, naturalize power relations. Polanyi [47] stresses that the false imaginary of the economy as a naturally self-regulating system subjects society to the market, producing inevitable problems and contradictions. Following these ideas, this section explores the problems with overemphasizing the efficiency discourse within water management.

\subsection{Where Do Winners and Losers Come From?}

Objections to studying and considering equity in public policy inevitably arise. Orthodox public policy prizes efficiency above all else, and for dominant efficiency models, equity is irrelevant and ignored [48]. Thus, unequal distribution is not a problem of concern. Two of the most influential economists on the hegemonic idea of efficiency illustrate this situation. For Coase [23], under a scenario of zero transaction costs, resources can be most efficiently allocated though private bargaining no matter what their original distribution. Thus original unequal distribution is not a problem as long as a free market ensures an efficient allocation. Meanwhile Hayek, expressly arguing against distributive justice, says that:

The concrete results of the catallaxy (spontaneous order of the market) for particular people are, however, essentially unpredictable; and since they are not the effect of anyone's design or intentions, it is meaningless to describe the manner in which the market distributes the good things of this world among particular people as just or unjust [49], p. 360 .

This passage illustrates Hayek's efforts to naturalize the unequal distribution of resources as an outcome of the spontaneous order of the market. Within the context of water management, the salient points of Coase's and Hayek's theses are straightforward: Under a free market model, we should not care about the unequal distribution of water; it is an inevitable, unintended consequence of the market, and it does not affect social efficiency. The spontaneous order should be left alone. Efficiency will emerge naturally. On the contrary, when equity is the object of regulation, it creates political noise that alters the model.

In summary, this approach answers the question of where winners and losers come from by arguing that they are naturally produced by the market; at the same time, it dismisses the question as completely irrelevant as long as there is a free market model ensuring efficiency. Bromley, criticizing these ideas, turns the above arguments around.

When discourse on efficiency began gaining influence in water and natural resource management circles in the early 1980s, Bromley [4,50] presented a powerful and simple critique on its natural and neutral aspirations. Specifically addressing the problem of 
the neoclassical ideas of efficiency within the context of water and land management, he argues that the economic devotion to Pareto and Kaldor-Hicks efficiency "is based on the widespread belief that economic efficiency is the only matter on which economists can pass scientific judgment" [4], p. 834. Deconstructing the abstract imaginary of economic efficiency, Bromley throws an accurate theoretical dart at the image of efficiency as natural, morally right, neutral, and isolated from equity, politics, and institutions.

Neoclassical economics roots efficiency in prices that emerge from competitive equilibrium. Where, though, do prices come from, Bromley [4] asks. The answer is not a mystery for neoclassical economists-in two words: demand and supply. In contrast to this perspective, which sees demand and supply as pre-given factors, Bromley [4] asserts that they are institutionally produced. Demand and supply depend on the rules that govern wealth distribution. These are the distributive justice rules, whose content relies on the equal distribution of wealth as an ideal and guiding principle of legal reasoning. While wealth position determines demand through purchasing power of scarce resources, it is also the source of supply so long as it determines how long an individual can abstain from engaging in market transactions. Thus, for Bromley, efficiency is not natural, and the distribution of wealth, rather than being the unintended consequence of the market, is actually the source of market behavior. In sum, the rules of equity determine efficiency, and these rules do not emerge from any spontaneous order; rather, they are politically produced. Regarding water, Bromley's arguments invite politicization of the water debate. In water management, winners and losers, rather than arising as a natural outcome, are institutionally produced. Thus, winners and losers come from politics, and this invites formulation of the copulative questions of who is in control of the rules that determine the management of water, who receives the benefits from a particular use and distribution pattern, and who suffers the costs of these patterns. According to Bromley [4], the answers to these politized questions determine efficiency.

As part of a broader neoliberal economic reform, the Chilean military dictatorship (1973-1990) imposed a new Water Code, which is known as a textbook example of a freemarket system for managing water resources [37,39,51]. Under this model, water rights became freely tradable and separate from the land within the context of private property reinforcement and minimal state regulation. This model illustrates how problematic it can be to displace equity concerns with an overemphasis on efficiency. Bauer [37] shows that equity is an absent issue within the Chilean case and notes that, despite the clear social impacts of the model, several authors ignore the empirical evidence and applaud the Chilean model for allowing an efficient outcome.

The Aymara indigenous community of Quillagua in the Atacama Desert is a paradigmatic case. Quillagua, an oasis formed by the waters of the Loa River, was once a green spot in the middle of the driest place on the earth. With the creation of water markets in 1981, however, waters in Quillagua were privatized. While some rights were directly given to mining companies through original allocation, the rights kept within the community were rapidly sold to these companies. Currently the oasis is practically dry, people have migrated, crops have disappeared, and biodiversity has diminished along the river basin. A few restaurants for truckers are practically the only sources of income. However, Donoso [52] argues that, in the Loa River region, markets have successfully operated, ensuring economic efficiency as long as the water that was once used in agriculture now benefits the mining sector, the main source of Chilean income. Consequently, the water market "has allowed the development of mining activities in areas of water scarcity through the purchase of water rights from the agriculture sector" [52], p. 47. In this context, who cares about the Aymara? To neoclassical and the neoliberal economists, the Aymaras do not constitute a problem; meanwhile, Kaldor-Hicks (hypothetically) compensates them. Against this perspective, authors like Bromley and a political ecological approach invite us to denaturalize this perspective and study the historical patterns, institutions, and sources of inequality that, through accumulation by dispossession [53], have determined the "efficiency" of the market. 


\subsection{Utilitarian Value vs. Community Value}

Utilitarianism has been the object of several critiques [16]. Among others, the most common show the unethical outcomes of utilitarianism's assumptions, such as the possibility of justifying the slavery of some people if it increases the aggregative happiness of society. These critiques have found an echo within the context of water debates, where the utilitarian arguments behind the water efficiency discourse have been heavily problematized. For example, Bromley [4] argues that collective values of water can be greater than the simple utilitarian aggregative calculus. Ingram, throughout her career, has pushed this argument in order to show how problematic and narrow the idea of economic efficiency is for those multiple water values that are not captured by a unique price value.

Water has multiple values attached to heterogeneous meanings and feelings [2,3]. This is the basic tension behind the Marxist discussion about use and exchange value. Indeed, water is not merely pure $\mathrm{H}_{2} \mathrm{O}[40,41,54]$ that can be reduced to a simple volumetric commodity [1]. Water takes on diverse meanings to diverse peoples and communities; thus, the economic value of water captures only one of them $[3,55]$. Contrary to the tragedy of the commons approach, communities of water users can develop sustainable water management solutions based on shared values, cooperation, and collective hydraulic property [56,57]. Several examples illustrate this. In northern New Mexico, through the acequia systems, Hispanics have built a strong sense of community through the sharing of water [2]. Trawick [58] similarly shows that, in Peru's Huaynacotas district, the communitarian meaning of water creates a transparent and equitable community ensuring material symmetry and/or proportionality as the general rule. Finally, in my own fieldwork in the Atacama Desert, I have noted that water rituals produce an understanding of water as a subject with agency that demands special treatment and strong community engagement [59].

In all these examples, diverse values and meanings of water create a level of complexity that pollutes the aseptic model of efficiency, which requires standard measures. This is why efficiency discourse ignores, simplifies, and standardizes water's meanings and values in order to measure and compare outcomes objectively. The overemphasis on economic value tries to capture the multiple water values and meanings through an abstract and unique efficiency model based on price value and commodity meaning. Under this scheme, water is disembodied from its social context and becomes an abstract and commensurable symbol for simplifying social choices. However, simplification is controversial [60] and produces problematic and unexpected outcomes. Water is not an exception; the Cochabamba water war illustrates this.

Bolivia's Cochabamba water war is a paradigmatic case of efficiency colliding with the communitarian value of water [46,61]. In 2000, the former president of Bolivia, Hugo Banzer, following the conditions imposed by the World Bank for renewing a loan, privatized the water services of the city, established a pricing scheme based on full cost recovery, and imposed restrictions on public access. These reforms aimed to increase water delivery capacity and water quality. Despite promises to the contrary, indigenous and poor urban water users were marginalized from the decision-making process, local meanings and values were ignored, and prices of water were disproportional to the average income. All these factors produced a social revolt. Embracing the communitarian value of water (reproduced through local customary rules locally known in as usos y costumbres) as a battle flag, people challenged the reforms in the streets. After months of violent conflicts, the reforms and the privatization were reversed. This case is an example of how efficiency applies a strict utilitarian perspective onto water that invisibilizes its multiple meanings and value. While the reforms viewed water as a simple object susceptible to pricing, the people held fast to water's cultural, practical, and material meanings that transcend both its meaning as a commodity and its price value. As long as these meanings and values were completely ignored, the universal and technical solution for increasing quality and availability failed to the extent that the privatization process was reversed. The Cochabamba war proves Polanyi's thesis [47]: The only spontaneous feature of the laissez faire economy is social resistance. 


\section{The Equity Response: From Commodity toward Human Right}

In the previous section I showed that overemphasis on economic efficiency discourse can produce controversial effects, such as accumulation by dispossession, unfair distributive outcomes, and environmental impacts. This situation has motivated the emergence of a strong opposition that challenges the institutional reforms proposed by the efficiency model. Aligning with Polanyi [47] and O'Connor [62], the opposition insists that the institutional overemphasis on efficiency has introduced the destructive logic of the market within water management. This creates certain irreconcilable contradictions that demand the displacement of efficiency by equity as the guiding ideal for developing a just society.

At the core of the equity problem is the question "What are the principles for guiding fair distribution of ownership?" As discussed, the discourse on economic efficiency has given a sharp response to this question. Rooted in a theoretical assemblage of classical liberalism, libertarianism, and utilitarianism, the efficiency discourse supports an objective and universalized normative principle of justice that affirms that the state should restrict its function to exclusively protecting property rights for engaging in capitalist market exchanges and intervene only in cases of market failure that cannot be solved by private negotiations. Under this approach, inequalities in wealth distribution should be let alone. Here, equity is not a problem of distribution of wealth; rather, it is entirely a problem of equal distribution of opportunities, and the free market, private property, and a neutral rule of law are the only institutional means for ensuring that distribution $[33,63]$. On the other hand, egalitarian perspectives on equity have projected a wholly different picture, which, in turn, has become the theoretical impetus behind offensives against the hegemonic role that efficiency has gained within water politics.

Despite the differences among diverse authors and schools of thought [15,64], the egalitarian's nonnegotiable bottom line for water debates is clear: The state should promote and ensure equality at the level of the material distribution of water, whether the distribution satisfies economic efficiency standards or not. The principal outcome of this perspective is the recognition of the necessity for re-embedding the hypothetically self-regulated economy in society, which for water management, means that water issues should be understood as a matter of politics rather than as a purely technical economic problem $[4,50]$. From this perspective, the agenda that pushes for water pricing, privatization, and commoditization as the axioms of water management is heavily challenged, especially by those who embrace the human-right-to-water view.

\subsection{The Human-Right-to-Water View}

The human-right-to-water view has been a key opponent of the pro-privatization and pro-market agenda pushed by the efficiency discourse $[6,29,65]$. Associating the egalitarian perspective on equity with the idea of water as essential for life and culture, opponents to the efficiency agenda have demanded the recognition of water as a human right $[66,67]$. This human-right-to-water view has been a key factor for building bridges between a wide range of social forces [6]. A network formed by scholars, NGOs, grassroots movements, politicians, and development agencies has articulated the idea of the human right to water as the institutional materialization, at the highest legal level, of the principle of equity. The underlying principle is that without a certain degree of equality at the material level of society, equal opportunity is just an abstract imaginary with no practical meaning. Consequently, water equity, as the guiding principle for water management, requires the recognition of certain egalitarian patterns of distribution of holding (a social-economic right), which stands in contrast to the understanding of water equity as abstract equal opportunity (a civil-political right). This means that water is much more than a common good [6]. While water as a public good supposes only public ownership, water as a human right constitutes a guarantee that the state should ensure equal access to water and non-discrimination, fair prices (that water users would pay according to their situation), prevention of abuse by the private sector, consideration of equity in legal changes, and accountability. In sum, the human-right-to-water view locates responsibility within all 
branches of the state and, at the same time, empowers citizens to claim their rights against it. This clearly defeats the principles of law and economics and defends (at least discursively) common property as preferable, regulation of contracts and markets as a means for reaching equity, the regulation of tariffs, the essential role of judges in resolving conflict according to equity principles, and the codification of principles of equity through regulations.

The articulation of the anti-privatization campaign within the discourse of the human right to water has allowed activists to acquire support from mainstream international development agencies, such as the World Health Organization, the United Nations Development Program, and the United Nations General Assembly [29]. This support has given the human right to water a high political priority in international debates. Indeed, in September 2010, the Human Rights Council of the United Nations approved a resolution affirming that the human right to water is grounded in existing international law. The difference from diverse previous resolutions and comments (see, e.g., General Comment No. 15 of the Committee on Economic, Social and Cultural Rights) is that for the first time this right is legally considered as binding upon states that are party to the International Covenant on Economic, Social and Cultural Rights [6,29]. At a national level, some countries have also explicitly recognized the human right to water (Democratic Republic of Congo, Ecuador, Kenya, Nicaragua, South Africa, Uganda, and Uruguay).

\subsection{What Does Equity Mean? Main Approaches}

A core component of the human rights framework is that water pricing and water allocation should be determined within the framework of social equity, and all development initiatives and institutional changes should be designed to enable equity. What, though, does equity mean, and what are the specific institutional changes, beyond the recognition of the human right to water, demanded by equity?

Answering these questions is not a difficulty exclusively faced by water management; on the contrary, within the distributive justice debates, scholars have tried to resolve precisely these questions. Indeed, several scholars have pushed the equity agenda and have offered guiding principles for policy changes. Among them, authors embracing strict egalitarism [68-70], Dworkin [71], and Rawls [72] are at the center of the debate. Their ideas, applied to the context of water, are explained below.

From a strict egalitarianism standpoint, all members of a society should have an equal right to water access. In policy terms, this means that the state must ensure equal distribution, no matter the costs. In addition, the state must ensure material conditions that guarantee equal power to use water. Scholars have various approaches to this position. For example, for Dworkin [71], the distribution of water is not satisfactory if, after the distribution, a person envies another because of a bundle of resources the other person has received. In institutional terms, the outcome of this theory is a complex system of taxes, regulations, and money-transfer of the welfare state that aims to remove the impacts on water distribution of those factors that are not under the control of individuals. Alternatively, Rawls [72] seeks to determine the principles of a just society with the help of hypothetical contracts among the society's hypothetical members. These hypothetical members are self-interested and rational but ignorant to their position or condition (e.g., class, gender, race, talents, and physical or intellectual aptitude). Within the context of water debates, these subjects will accept unequal water distribution only if it benefits everybody (including the least-advantaged individuals). In policy terms, this implies an institutional framework that ensures that the compensations of the Pareto efficiency model actually occur in reality.

Scholars have sought to apply the previous frameworks in their research agendas (see, e.g., Ingram [38] using Rawls's and Kant's distributive principles), to summarize general principles of equitable allocation [73], or to induce principles from ethnographies and case studies [58]. However equity is still a vague concept. This fact is not a problem; rather, it constitutes the major strength of the idea of equity. As long as equity appears as a contested, diverse, and situated concept, we can approach water management as 
a politically negotiated concept rather than as a purely technical issue. Nevertheless, this has not been the dominant perspective on equity. The naturalization of the idea of equity as a universal concept and its instrumentalization through the human-right-to-water framework implies several problems that I explore in the following section.

\section{Problematizing Equity}

Contemporary egalitarian discourses on equity and human rights have shared with libertarianism the same Enlightenment conceptualization of the subject. For both libertarians and egalitarians, all subjects are rational individuals who demand equal treatment as moral beings. How these approaches differ, however, is in defining the treatment such equal status requires [15]. The consequences of this shared root are significant and, indeed, highly problematic for the current water debates. In this section, I argue that, far from being a panacea, the idea of water equity and its institutional materialization through the human-right-to-water frame presents several flaws that should be considered.

\subsection{What Is Equity?}

The idea of equity as a universal category rooted in a certain inevitable human essence, rather than embodied in specific contexts, is highly problematic. The concepts of equity, equality, and fairness that water institutions aim to achieve are not precisely defined for those in disadvantaged positions, who have been historically disposed and marginalized from water access and decision-making. This fact raises controversial issues, especially in cross-cultural situations, where the principle of equity can operate as a means for reproducing historical social inequalities rooted in colonial dynamics.

Diverse theories have sought to define what water equity should be [48] rather than explore how water equity is defined [74]. This approach tends to ignore that it is a situated concept. As such, it is articulated by particular subjects in specific places, historical moments, and ecological contexts in order to solve certain problems [75]. On the contrary, universal approaches naturalize a unique conceptualization of equity and, at the same time, erase differences in order to produce assimilation and exploitation [76,77]. When ideas of equity are imposed from above as a universal principle, they function to promote the interests and domination of those who hold power and define equity, while leading to the destruction and/or fixation of diverse and changing rules and equity perceptions [74]. In this sense, equity and human right discourses can suffer exactly the same problem as economic efficiency when they appear as the pre-given and natural results of inevitable power relations. When this happens, equity loses its major value, that is, its ability to become a political driver.

Several cases show the state, in the name of a certain universal idea of equity, ignoring local conceptions and thus producing undesirable outcomes. For example, Trawick [58] explains that the Peruvian state has, by imposing a centralized water model that aimed to materialize universal conceptions of fairness, dismissed indigenous moral economies of water. The moral economy of water is a concrete ethic rooted in communitarian values for coordinating water's proper usage. The Peruvian state intervention has prolonged and intensified a legacy of tragedy and water conflict. Problematic situations are not exclusive to the obvious examples offered by postcolonial situations. Oliveiro [77] studies how the modern Italian state, in both its fascist and the liberal democratic iterations, has imposed a universal idea of national water equity. This universal idea of national water equity has been the main political justification for diverting water away from the lands of traditional farmers toward big corporations, a situation that has affected diverse local water practices and conceptions on equity.

Universal imaginaries on equity are not just problematic within the state-centric approach. Recently, equity has been instrumentalized to push the efficiency agenda. Proponents of the efficiency paradigm present equity, human rights to water, and efficiency as fully compatible. Indeed they insist that privatization and markets are a guarantee of equity that directly benefits the poor by ensuring better access, greater participation, lower 
prices, and less corruption [78]. For example the World Bank, reflecting on the Chilean case, argues that "the humanitarian and equity aspects of water allocation are likely to be better under a market regime" ([79], p. 15), adding that "tradable water rights can benefit the poor and increase user participation in water allocation and investment decisions" ([79], p. 20). In addition, the Integrated Water Resource Management (IWRM) agenda-the IWRM is "a process which promotes the coordinated development and management of water, land and related resources, in order to maximize the resultant economic and social welfare in an equitable manner without compromising the sustainability of vital ecosystems" [80], p. 22. The IWRM framework has been widely promoted by international agencies such as the Global Water Partnership-has positioned equity and efficiency as goals with equal levels of importance [80]. Furthermore, several actors that push for the implementation of the efficiency framework, including radical libertarian thinks tanks, like the Cato Institute, have presented privatization and property as both a guarantee for equity and the best means for satisfying the human right to water $[29,65]$.

\subsection{Equity for Whom?}

The principle of equity, in addition to ensuring certain rights to individuals, imposes the idea that there is a unique model of subject. If water equity is rooted in the idea that all subjects are equal, the key questions are "Equal to whom? And who must be equal to whom?" [74], p. 18. Generally, the discourse of equity tends to equalize people under the same category of subject, which is seen as pre-given rather than historically situated. This situation neglects the historical and social background from which subjects gain recognition and meaning [81]. Within the context of water issues, in addition to producing theoretical moral dilemmas, the idea of the equal subject has concrete, material, and uneven outcomes.

Equity tends to present subjects as sharing a certain essence that makes them abstractly equal. When this imaginary is expressed through legal institutions, such as the human right to water ("official equity"), it tends to erase the intrinsic diversity of people and their knowledge and enforce the idea of a universal subject. Through the construction of this equal subject, the powerless become objects of control and exploitation [74,82]. This imaginary erases historical patterns and sources of exploitation, dispossession, and uneven distribution of water. Current social inequalities are not pre-given, rather they have been historically constructed through power relations. With the negation of these material asymmetries through abstract legal symmetries, this approach ignores and conceals the historical patterns and sources of unequal water distribution. This situation limits the problem of water equity to the question of how to fairly distribute water among preconstituted subjects within a pre-given social position, rather than problematizing the origins of unequal water distribution and exploitation

A clear example of this flaw appears in the South African Constitution, which expressly adopted the human right to water for all citizens in 1996. Despite this formal recognition, the constitutional implementation of the right to water has ignored historical patterns of exclusion that have determined the marginalization of black South Africans. In turn, this marginalization has directly impacted the current uneven distribution and provision of water by privileging white communities [29]. This case demonstrates that as long as the historical roots that have determined asymmetries between subject positions are ignored, this right is merely a legal fetish.

A second problem with the idea of the equal subject is related to the consequences of the imposition of a shared identity. When subjects are equalized, there emerge certain reciprocal duties that can produce unfair social outcomes. Equal subjects have equal rights and duties. This synonymic relation has served the powerful as a key argument for reproducing exploitation. Indeed, classical examples of accumulation by dispossession [53] are rooted in the idea of the equal subject. In southern Chile, famous judicial rulings on hydroelectric conflicts between the electric company ENDESA (Empresa Nacional de Electricidad) and the Pehuenche indigenous communities (see Ranco and Pangue case) are examples of the unfair outcomes produced by the idea of equality [39]. In these conflicts, 
the Pehuenche invoked in court their constitutional right to equality in order to stop the construction of a hydroelectric dam on their lands. However, the courts also considered the right to equality invoked by hydroelectric companies, dismissing the indigenous lawsuits. Far north of this case, in the Atacama Desert, the exploitation of water aquifers for ensuring mining development (mainly copper and lithium) located on Aymara and Atacameño indigenous lands are justified under rhetoric that presents them as Chilean citizens, ignoring cultural differences, years of colonialism, racism, and dispossession.

\subsection{Equity and the Human Right to Water: The Main Problems}

The human rights framework, equity, and capitalism are interwoven through the principles of the Enlightenment conceptualization. This creates certain problems in articulating a serious opposition against the efficiency imaginary in the human-right-to-water discourse.

First, human rights are individual rights, and this is problematic for water management. As an individual right, the human right to water is not a guarantee for protecting water as collective property. Even more, it can be used as a means for enclosure, implying the transformation of common resources into individual property and excluding the communities to which they are connected.

Second, private property is also widely recognized as a human right. Other economic rights have been raised to a human rights level (e.g., in Chile, economic freedom is considered a human right in the constitution imposed by the military regime in 1980 [83]). Consequently, the human right to water is not necessarily a guarantee against privatization. Indeed, it can function as a means for increasing the private sector's power [65].

Third, the human right to water implies a high degree of state responsibility. A strict interpretation of the human right to water can lead to a state-centric perspective that does not necessarily guarantee fairness and participation. Indeed, the human right to water can serve as a means through which the state can legitimate and expand its power. This is especially important in cross-cultural contexts where the state can legitimize the disruption of communitarian values and practices [76].

Fourth, the human right to water is a human right, not a more-than-human right. The anthropocentric roots of the human-right-to-water position the human within a privileged position with regard to water, which is reduced to a mere object of appropriation by humans. This can produce situations of over-exploitation and over-allocation at the expense of the environment. Furthermore, this over-exploitation and over-allocation can, contradictorily, produce degradation of the hydrological systems upon which this right depends [65].

\section{Discussion: Toward the Political Ecology of Water Equity}

The discussion presented in this paper reveals the considerable ink that has been spilled on the efficiency and equity debate. Great intellectual and political effort has problematized the general assumptions behind the idea of efficiency. Despite the important role that equity has played as an oppositional concept against efficiency, this paper has critically examined the main flaws of both this concept and its articulation through the idea of the human right to water. After analyzing these flaws, I demonstrate that the tension between efficiency and equity is rooted in these concepts' common ambition to be seen as universal categories. While efficiency is presented as emerging from the natural laws of the market, equity is seen as part of human nature. Both concepts appear inevitable and, as such, inherently incompatible. The risk of this situation is that equity and the human right to water appear as apolitical tools that could lose their power as concepts that lead to social and ecological transformation. Critical literature on water management, recognizing that equity is a protean and situated ideal, has provided a political basis to the aspiration for water equity (e.g., recognizing different values and rationalities of water; considering intergenerational equity; accounting for community interests; acknowledging more-than-human actors; fostering open, participatory, and transparent decision-making; addressing power imbalances, and recognizing collective hydraulic property) $[3,84]$. The political ecology framework is useful for pushing this effort forward, overcoming this 
tension and weakness, and serving as a methodological and theoretical tool to implement equity and the human right to water.

Political ecology aims to reveal those assumptions that, by naturalizing conditions and explanations of the human-environment relationship, present power asymmetries as inevitable [85]. Thus, political ecology as a critique is useful not only for denaturalizing the assumptions behind the ideas of equity and efficiency but also for denaturalizing the tension that exists when both concepts are seen as universal categories. Reflecting on the efficiency/equity tension through political ecology as a critique necessarily supposes a change of focus. Both efficiency and equity discourses view the allocation problem as strictly related to the distribution of pre-given objects among ahistorical subjects. This perspective ignores the fact that water and scarcity are actually socially constructed $[86,87]$ and subjects are historically situated. On the contrary, political ecology offers an invitation to overcome the efficiency/equity tension by moving toward the analysis of power distribution among historically situated subjects.

In relation to water issues, this means that research agendas and critiques on the efficiency/equity debate should avoid thinking about water as a pre-given and inevitable good that precedes and remains external to politics and the economy. It should, further, eschew approaches that make water the object of rules of distribution among subjects. Instead, in a political ecology critique, any approach to the efficiency/equity debate on water must take a different direction.

First, the political ecology of water has shown that water does not exist as a pre-given entity that can be simply reduced to $\mathrm{H}_{2} \mathrm{O}[40,41,54,88]$. Instead, water has a socio-natural ontology, in the sense that "is a 'hybrid' thing that captures and embodies processes that are simultaneously material, discursive, and symbolic" [54], p. 28. Within this context, the research agenda on water equity should interrogate those power relations that mediate the process through which water comes into being as both a material and discursive entity.

Second, the subjects that participate in these relations of power do not precede them; they are also constituted through them $[89,90]$. Class, gender, and race identities are context dependent and come into being through highly politicized processes that determine the asymmetries of power within water allocation [90]. In this sense, the modes through which people recognized themselves [91] and are recognized by others are interwoven with capitalist, patriarchal, colonial, and neocolonial dynamics that determine relations of exploitation and exclusion with regard to water [92]. In this sense, "the task is to identify the ways in which racism, cultural oppression and identity interact with economic forces to create unique forms of domination and exploitation" [93], pp. 192-193.

These two considerations lead to an understanding that the struggles for water equity cannot be divorced from the larger struggles over repression and subjugation through which both water and actors are constituted. The main conclusion from this finding is that the problems posed by distributive justice, as the central question of a water efficiency/equity tension, should not begin by asking what is the most equitable or efficient model for water distribution. Indeed, this question only makes sense once a more essential question-how the current uneven power relations with respect to water are and have been produced-is answered. In sum, it is necessary to go beyond the normative question of how distribution should look to achieve equity and/or efficiency and start thinking first about what determines and gives rise to poor distribution and situations of inequity [94].

This conclusion leads me to formulate four recommendations for informing the water research agenda and its potential contribution to the academic and policy debate on efficiency/equity.

First, it is necessary to approach with suspicion any essentialist formulation of what water equity should look like. Formulations of equity, like formulations of efficiency, are not neutral concepts but are, like formulations of efficiency, rooted in power relations. In this sense, before embracing any formulation of water equity, it is necessary to examine the questions of who defines equity, under which systems of truth equity is defined, and who the winners and losers of these definitions are. This position de-romanticizes some 
approaches that tend to reproduce the noble savage colonial imaginary and ignore the fact that, even within traditional conceptions of equity (e.g., indigenous communities), asymmetries of power with uneven outcomes nevertheless arise [46,95].

Second, identity politics should be taken seriously. Cultural identity is a key element for discussing equity and, consequently, achieving environmental justice [93]. Identity politics has consequences for institutional reforms that aim to achieve a substantial, equitable redistribution [92]. Reforms cannot work in a vacuum, and they cannot be imposed on a pre-constituted society. Rather, reforms should be accompanied by a revision of previous power relations, cultural practices, capabilities, material inequality, and systems of meaning that constitute subjects as different and particular actors [93,96,97].

Third, institutions that aim to achieve procedural justice through greater transparency and democratic participation should not be seen as synonymous with greater equity. Material inequalities, colonialism, racial and gender disparities, and cultural misrecognitions must be addressed first $[45,51,96]$.

Finally, the theoretical and empirical dimensions of the right to water framework should be politicized. Otherwise, it faces the risk of becoming an empty concept [98]. This leads academics, students, policymakers, and activists to interrogate the right to water not as the final result of a political process, but as a critical research agenda that should aim to impart a political meaning to the right to water for its mobilization as a powerful tool for reaching water justice.

Funding: This research was funded by the Chilean National Agency for Research and Development (Agencia Nacional de Investigación y Desarrollo de Chile, ANID), FONDECYT 1201527, FONDAP 15110006, PIA SOC180023; and Universidad de Tarapacá, Proyecto UTA Mayor No 5784-20.

Acknowledgments: I thank Carl Bauer, Paul Robbins, Sallie Marston, and Thérèse de Vet for their comments on an early draft of this paper, Francisco Saffie for his valuable advice, and the anonymous referees for their constructive feedback. The author alone is responsible for the content of the paper.

Conflicts of Interest: The author declares no conflict of interest.

\section{References}

1. Kelso, M. The Water is Different Syndrome, or What is Wrong with the Water Industry. In Proceedings of the American Water Resources Association, San Francisco, CA, USA, 9 November 1967.

2. Brown, F.L.; Ingram, H.M. Water and Poverty in the Southwest; University of Arizona Press: Tucson, AZ, USA, 1987.

3. Ingram, H.; Whiteley, J.M.; Perry, R. The Importance of Equity and the Limits of Efficiency in Water Resources. In The Importance of Equity and the Limits of Efficiency in Water Resources; Ingram, H., Whiteley, J.M., Perry, R., Eds.; The MIT Press: Cambridge, MA, USA, 2008; pp. 1-32.

4. Bromley, D.W. Land and water problems: An institutional perspective. Am. J. Agric. Econ. 1982, 64, 834-844.

5. Mercuro, N.; Medema, S.G. Economics and the Law: From Posner to Postmodernism and Beyond; Princeton University Press: Princeton, NJ, USA, 2006.

6. Conca, K. Governing Water: Contentious Transnational Politics and Global Institution Building; MIT Press: Cambridge, MA, USA, 2013.

7. Pareto, V.F.D. Manual of Political Economy; Macmillan: London, UK, 1971.

8. Orbach, B. Regulation: Why and How the State Regulates; Foundation Press: St. Paul, MN, USA, 2012.

9. Stigler, G.J.; Friedland, C. What Can Regulators Regulate? The Case of Electricity. J. Law Econ. 1962, 5, 1-16.

10. Stigler, G.I. The Theory of Economic Regulation Bell. J. Econ. Manag. Sci. 1971, 2, 3-21.

11. Peltzman, S. Toward a More General Theory of Regulation. J. Law Econ. 1976, 19, 211-240.

12. Tullock, G. The welfare costs of tariffs, monopolies, and theft. Econ. Inq. 1967, 5, $224-232$.

13. Krueger, A. The Political Economy of the Rent-Seeking Society. Am. Econ. Rev. 1974, 64, 291-303.

14. Williams, R. Keywords: A Vocabulary of Culture and Society; Fontana: London, UK, 1976.

15. Christman, J. Social and Political Philosophy: A Contemporary Introduction; Routledge: London, UK; New York, NY, USA, 2002.

16. Scruton, R. Modern Philosophy: A Survey; Sinclair-Stevenson: London, UK, 1994.

17. Sen, A. On Economic Inequality; Oxford University Press: New York, NY, USA, 1997.

18. Brink, D. Utilitarian Morality and the Personal Point of View. J. Philos. 1986, 83, 417-438.

19. Luhmann, N. Rechtssystem und Rechtsdogmatik; W. Kohlhammer: Stuttgart, Germany, 1974.

20. Posner, R.A. The Economics of Justice; Harvard University Press: Cambridge, MA, USA, 1996.

21. Demsetz, H. Towards a Theory of Property Rights; Edward Elgar Publishing Ltd: Cheltenham, UK, 2003.

22. Von Mises, L. Socialism: An Economic and Sociological Analysis; J. Cape: London, UK, 1951. 
23. Coase, R. The problem of social cost. J. Law Econ. 1960, 3, 1-44.

24. Hardin, G. The Tragedy of the Commons. Science 1968, 162, 1243-1248.

25. Anderson, T.; Leal, D. Free Market Environmentalism; Pacific Research Institute for Public Policy: San Francisco, CA, USA; Westview Press: Boulder, CO, USA, 2001.

26. Cheung, S.N.S. The Myth of Social Cost: A Critique of Welfare Economics and the Implications for Public Policy; Institute of Economic Affairs: London, UK, 1978.

27. Worster, D. Rivers of Empire: Water, Aridity, and the Growth of the American West; Pantheon Books: New York, NY, USA, 1985.

28. Saurí, D.; Moral, L.D. Recent developments in Spanish water policy. Alternatives and conflicts at the end of the hydraulic age. Geoforum 2001, 32, 351-362.

29. Bakker, K. Privatizing Water. Governance Failure and the World's Water Crisis; Cornell University Press: Ithaca, NY, USA, 2010.

30. Swyngedouw, E. Modernity and Hybridity: Nature, Regeneracionismo, and the Production of the Spanish Waterscape, 1890-1930. Ann. Assoc. Am. Geogr. 1999, 89, 443-465. [CrossRef]

31. Wittfogel, K.A. Oriental Despotism; A Comparative Study of Total Power; Yale University Press: New Haven, CT, USA, 1957.

32. Reisner, M. Cadillac Desert: The American West and Its Disappearing Water; Penguin Books: New York, NY, USA, 1993.

33. Hayek, F. The Constitution of Liberty; University of Chicago Press: Chicago, IL, USA, 1960.

34. Anderson, T. The market process and environmental amenities. In Reconciling Economics and the Environment; Block, W., Ed.; Australian Institute for Public Policy: Perth, Australia, 1991; pp. 133-150.

35. Thobani, M. Tradable Property Rights to Water How to Improve Water Use and Resolve Water Conflicts; The World Bank: Washington, DC, USA, 1995; pp. 1-4.

36. Briscoe, J. Water as an economic good: The idea and what it means in practice. In Proceedings of the World Congress of International Commission on Irrigation and Drainage, Cairo, Egypt, 15-22 September 1996.

37. Bauer, C. Siren Song: Chilean Water Law as A Model for International Reform; Resources for the Future: Washington, DC, USA, 2004.

38. Ingram, H.; Feldman, D.; Whiteley, J.M. Water and Equity in a Changing Climate. In Water, Place, and Equity; Ingram, H., Whiteley, J.M., Perry, R., Eds.; The MIT Press: Cambridge, MA, USA, 2008; pp. 271-308.

39. Bauer, C. Against the Current: Privatization, Water Markets, and the State in Chile; Kluwer Academic Publishers: Boston, MA, USA, 1998.

40. Bakker, K. From state to market?: Water mercantilización in Spain. Environ. Plan. A 2002, 34, 767-790. [CrossRef]

41. Bakker, K. An Uncooperative Commodity: Privatizing Water in England and Wales; Oxford University Press: Oxford, UK, 2004.

42. Prudham, S. Poisoning the well: Neoliberalism and the contamination of municipal water in Walkerton, Ontario. Geoforum 2004, 35, 343-359. [CrossRef]

43. Aguilera-Kink, F.; Sánchez-Garcia, J. Water markets in Tenerife: The conflicts between instrumental and ceremonial functions of the institutions. Int. J. Water 2005, 3, 166-185.

44. McDonald, D.; Ruiters, G. The Age of Commodity: Water Privatization in Southern Africa; Earthscan: London, UK, 2005.

45. Wilder, M. Equity and Water in Mexico's Changing Institutional Landscape. In Water, Place, and Equity; Whiteley, J.M., Ingram, H.M., Perry, R.W., Eds.; MIT Press: Cambridge, MA, USA, 2008.

46. Perreault, T. Custom and Contradiction: Rural Water Governance and the Politics of Usos y Costumbres in Bolivia's Irrigators' Movement. Ann. Assoc. Am. Geogr. 2008, 98, 834-854. [CrossRef]

47. Polanyi, K. The Great Transformation; Beacon Press: Boston, MA, USA, 1957.

48. Raymond, L. Private Rights in Public Resources: Equity and Property Allocation in Market-Based Environmental Policy; RFF Press: New York, NY, USA, 2003.

49. Hayek, F. The principles of a liberal social order. Il Politico 1966, 31, 601-618.

50. Bromley, D.W. Economic Interests and Institutions: The Conceptual Foundations of Public Policy; Basil Blackwell: New York, NY, USA, 1989.

51. Budds, J. Power, nature, and neoliberalism: The political ecology of water in Chile. Singap. J. Trop. Geogr. 2004, 25, 322-342. [CrossRef]

52. Donoso, G. Chile: Estudio de caso del Código de Aguas. In Mercados (de Derechos) de Agua: Experiencias y Propuestas en América del Sur; CEPAL, Ed.; Naciones Unidas, CEPAL: Santiago de Chile, Chile, 2004; pp. 25-48.

53. Harvey, D. The New Imperialism; Oxford University Press: Oxford, UK, 2003.

54. Swyngedouw, E. Social Power and the Urbanization of Water; Oxford University Press: Oxford, UK, 2004.

55. Blatter, J.; Ingram, H. Reflections on Water: New Approaches to Transboundary Conflicts and Cooperation; MIT Press: Cambridge, MA, USA, 2001.

56. Ostrom, E. Governing the Commons: The Evolution of Institutions for Collective Action; Cambridge University Press: Cambridge, UK; New York, NY, USA, 1990.

57. Lansing, J.S. Priests and Programmers: Technologies of Power in the Engineered Landscape of Bali; Princeton University Press: Princeton, NJ, USA, 1991.

58. Trawick, P. The Moral Economy of Water: Equity and Antiquity in the Andean Commons. Am. Anthropol. 2001, 103, 361-379. [CrossRef]

59. Prieto, M. Practicing costumbres and the decommodification of nature: The Chilean water markets and the Atacameño people. Geoforum 2016, 77, 28-39. [CrossRef] 
60. Scott, J.C. Seeing Like a State: How Certain Schemes to Improve the Human Condition Have Failed; Yale University Press: New Haven, CT, USA, 1998.

61. Madeline, B. The Global Water Crisis, Privatization, and the Bolivian Water War. In Water, Place, and Equity; Ingram, H., Whiteley, J.M., Perry, R., Eds.; The MIT Press: Cambridge, MA, USA, 2008; pp. 189-224.

62. O'Connor, J. The Second Contradiction of Capitalism. In The Greening of Marxism; Benton, T., Ed.; Guilford Press: New York, NY, USA, 1996; pp. 197-221.

63. Nozick, R. Anarchy, State, and Utopia; Basic Books: New York, NY, USA, 1974; p. xvi. 367p.

64. Fleischacker, S. A Short History of Distributive Justice; Harvard University Press: Cambridge, MA, USA; London, UK, 2004.

65. Bakker, K. The "Commons" Versus the "Commodity": Alter-globalization, Anti-privatization and the Human Right to Water in the Global South. Antipode 2007, 39, 430-455. [CrossRef]

66. Shiva, V. Water Wars: Privatization, Pollution, and Profit; Pluto Press: Lonsdon, UK, 2002.

67. Petrella, R. The Water Manifesto: Arguments for a World Water Contract; Zed Books: London, UK, 2001.

68. Hegel, G.W. The Philosophy of Right; Oxford University Press: Oxford, UK, 1967.

69. Cohen, G.A. Rescuing Justice and Equality; Harvard University Press: Cambridge, MA, USA, 2008.

70. Sen, A. Inequality Reexamined; University Press: Oxford, UK, 1992.

71. Dworkin, R. Sovereign Virtue: The Theory and Practice of Equality; Harvard University Press: Cambridge, MA, USA, 2002.

72. Rawls, J. A Theory of Justice; Belknap Press of Harvard University Press: Cambridge, MA, USA, 1971.

73. Wolf, A.T. Criteria for equitable allocations: The heart of international water conflict. Nat. Resour. Forum. 1999, 23, 30. [CrossRef]

74. Boelens, R. Equity and Rule Making. In Searching for Equity: Conceptions of Justice and Equity in Peasant Irrigation; Boelens, R., Dávila, G., Menchú, R., Eds.; Van Gorcum: Assen, The Netherlands, 1998; pp. 16-34.

75. Benda-Beckmann, F.v.; Benda-Beckmann, K.v.; Pradhan, R. Water rights, conflict and policy. In Proceedings of the International Irrigation Management, Institute Workshop, Kathmandu, Nepal, 22-24 January 1996.

76. Lauderdale, P. Justice and Equity: A Critical Perspective. In Searching for Equity: Conceptions of Justice and Equity in Peasant Irrigation; Boelens, R., Dávila, G., Menchú, R., Eds.; Van Gorcum: Assen, The Netherlands, 1998; pp. 5-10.

77. Oliveiro, A. Reclaiming Equality, Equity and Diversity. In Searching for Equity: Conceptions of Justice and Equity in Peasant Irrigation; Boelens, R., Dávila, G., Menchú, R., Eds.; Van Gorcum: Assen, The Netherlands, 1998; pp. 11-15.

78. Segerfeldt, F. Water for Sale: How Business and the Market Can Resolve the World's Water Crisis; Cato Institute: Lanham, MD, USA; Washington, DC, USA, 2005.

79. Holden, P.; Thobani, M. Tradable Water Rights: A Property Rights Approach to Resolving Water Shortages and Promoting Investment; World Bank: Washington, DC, USA, 1996.

80. GWP. Integrated Water Resources Management; Global Water Partnership (GWP): Stockholm, Sweden, 2000.

81. Taylor, C. The Ethics of Authenticity; Harvard University Press: Cambridge, MA, USA; London, UK, 2018.

82. Wainwright, J. Decolonizing Development: Colonial Power and the Maya; Blackwell Pub.: Malden, MA, USA, 2008.

83. Bauer, C. Derecho y Economía en la Constitución de 1980. Perspect. Política Econ. Gestión 1998, 2, $23-47$.

84. Wilder, M.; Ingram, H. Knowing Equity When We See It: Water Equity in Contemporary Global Contexts. In Oxford Handbook of Water Policy and Politics; Conca, K., Weinthal, E., Eds.; Oxford University Press: Oxford, UK, 2016.

85. Robbins, P. Political Ecology: A Critical Introduction; Blackwell: Malden, MA, USA, 2011.

86. Kaika, M. Constructing Scarcity and Sensationalising Water Politics: 170 Days That Shook Athens. Antipode 2003, 35, 919-954. [CrossRef]

87. Linton, J. What is Water? The History of a Modern Abstraction; UBC Press: Vancouver, BC, Canada, 2010.

88. Swyngedouw, E. Power, nature, and the city. The conquest of water and the political ecology of urbanization in Guayaquil, Ecuador: 1880-1990. Environ. Plan. A. 1997, 29, 311. [CrossRef]

89. Sundberg, J. Identities in the making: Conservation, gender and race in the Maya Biosphere Reserve, Guatemala. Gender Place Cult. 2004, 11, 43-66. [CrossRef]

90. Li, T. Articulating Indigenous Identity in Indonesia: Resource Politics and the Tribal Slot. Comp. Stud. Soc. Hist. 2000, 42, 149-179.

91. Perreault, T. El capitalismo, la naturaleza y la identidad social: Una teorización incompleta. In Justicia Hídrica: 7 Ensayos Como Aportes Para Articular las Luchas; Vélez Galeano, H., Ed.; CENSAT Agua Vida, Amigos de la Tierra: Bogotá, Colombia, 2010; pp. 67-79.

92. Boelens, R. Water, Power and Identity: The Cultural Politics of Water in the Andes; Routledge: New York, NY, USA, 2015.

93. Pulido, L. Environmentalism and Economic Justice: Two Chicano Struggles in the Southwest; University of Arizona Press: Tucson, AZ, USA, 1996.

94. Young, I. Justice and the Politics of Difference; Princeton University Press: Princeton, NJ, USA, 1990.

95. Guillet, D. Covering Ground: Communal Water Management and the State in the Peruvian Highlands; The University of Michigan Press: Ann Arbor, MI, USA, 1992.

96. Sundberg, J. Conservation and democratization: Constituting citizenship in the Maya Biosphere Reserve, Guatemala. Political Geogr. 2003, 22, 715-740. [CrossRef]

97. Schlosberg, D. Defining Environmental Justice. Theories Movemens, and Nature; Oxford University Press: Oxford, UK, 2007.

98. Sultana, F.; Loftus, A. The Right to Water: Politics, Governance and Social Struggles; Earthscan/Routledge: Milton Park, Abingdon, UK; New York, NY, USA, 2012. 